\title{
Geo-electrical Resistivity Evaluation of Groundwater Potential at University Of Benin Ugbowo Campus, Benin-City, Edo State of Nigeria, Using the Schlumberger Array
}

\author{
*1BASSEY, P; ${ }^{1}$ LAWRENCE, OO; ${ }^{2}$ AILEGO, J \\ ${ }^{* 1,2}$ Department of Science Laboratory Technology, Faculty of Life Sciences, University of Benin, Benin-City, Edo State \\ ${ }^{1}$ Department of Physics, Faculty of Physical Sciences, Federal University, Otuoke, Bayelsa State. \\ *Corresponding Author Email: peter.bassey@uniben.edu; Tel: +2348066834634
}

\begin{abstract}
Geo-electrical resistivity survey was conducted in part of the University of Benin, Benin-City, Ovia Northeast of Edo State, Nigeria, with a view to establishing the most dependable aquifer bearing zone and the lateral and vertical variation of subsurface lithology with distance and depth respectively. In this study, the schlumberger electrode configuration was employed for the acquisition of VES data in the field. A total of 6 VES stations were engaged within the study area. A, $\mathrm{H}$ and $\mathrm{HK}$ resistivity curve types were identified, reflecting facies or lithological variations in the area. Three patterns of geo-electrical resistivity curves obtained using IP2WIN software can be associated with different rock formations in the study area. Dar Zarruk Parameters were tools used for aquifer characterization in determining the groundwater potential of the area and capacity bearing rating, viz: Total transverse resistance $(\mathrm{T})$ and Total longitudinal conductance (S), Resistivity Contrast (RC) and Resistivity Reflection Coefficient (RRC). Results obtained shows that VES 1 (coordinate N6 23 '56.69', E5 $5^{\circ} 37^{\prime} 32.83^{\prime \prime}$ ') with four layers and an A curve type is the most potential source for groundwater compared to other VES points. It is a sandy clay layer of resistivity $198 \Omega \mathrm{m}$, with thickness to infinity and well confined at the top by a laterite layer. VES 1 has the highest Total Traverse Resistance $690310 \Omega \mathrm{m}^{2}$ (showing a very good transmmitivity of the layer), Resistivity Contrast ( 0.01$)$ and Resistivity Reflection Coefficient (0.90), all parameters falling within good prospect for groundwater development, but has a Total Longitudinal Conductance (S) value of 0.002 mho which shows that VES 1 has a poor bearing capacity. In summary, the results of the geo-electrical resistivity survey conducted at the Vice Chancellor's Lodge area of University of Benin using Schlumberger Array, revealed the most dependable aquifer bearing zone and the lateral and vertical variation of subsurface lithology with distance and depth respectively.
\end{abstract}

\section{DOI: $\underline{\text { https://dx.doi.org/10.4314/jasem.v23i9.23 }}$}

Copyright: Copyright $\left({ }^{\circ} 2019\right.$ Bassey et al. This is an open access article distributed under the Creative Commons Attribution License (CCL), which permits unrestricted use, distribution, and reproduction in any medium, provided the original work is properly cited.

Dates: Received: 06 August 2019; Revised: 12 September 2019; 29 September 2019

Keywords: Geo-electrical Resistivity, Aquifer, Subsurface Lithology, Benin-City

Water is so important for life sustenance; hence the need for effectual prospecting and successive determination of potential areas of groundwater accumulation is a serious matter to be dealt with. Resistivity techniques especially the Vertical Electrical Sounding (VES) method has been used for investigating subsurface layer properties and groundwater potential.

This method was found suitable for hydro-geological surveys in sedimentary rocks (Hadi, 2009). By this method, the subsurface characterization is determined based on the change of resistivity values with depth.

A VES is typically carried out in Schlumberger array, where the potential electrodes are placed in fixed positions with a short separation and the current electrodes are placed symmetrically on the outer sides of the potential electrodes.
However, the electrical formation resistivity is defined by the clay content of the formation with clayish less permeable formations revealing low resistivity and sandy permeable formations showing high resistivity. According to Chistensen and Sorensen (1998) and Sorensen et al. (2005), the geo-electrical method is capable of mapping both low and high resistive formations and therefore a valuable tool for vulnerability studies. Resistivity values can provide an overview of the groundwater type that exists in the study area. The Climate and geology of an area has a lot to tell about the geochemistry of its groundwater. Schlumberger array method was employed in this study with the view of determining the geo-electrical characteristic of the sub-surface layers and identifying suitable area with the most viable aquifers.

\section{MATERIALS AND METHOD}

Location of Study Site and Hydrogeological Setting: This study was carried out in University of Benin, Ugbowo Campus, Benin City, the capital of Edo State, 
Nigeria and is located in the south-south geopolitical zone of Nigeria; bounded by latitudes $6^{\mathrm{O}} 06^{\prime} \mathrm{N}, 6^{\mathrm{O}} 30^{\prime}$ $\mathrm{N}$ and longitudes $5^{\mathrm{O}} 30^{\prime} \mathrm{E}, 5^{\mathrm{O}} 45^{\prime} \mathrm{E}$ and area of about 500 square kilometers.

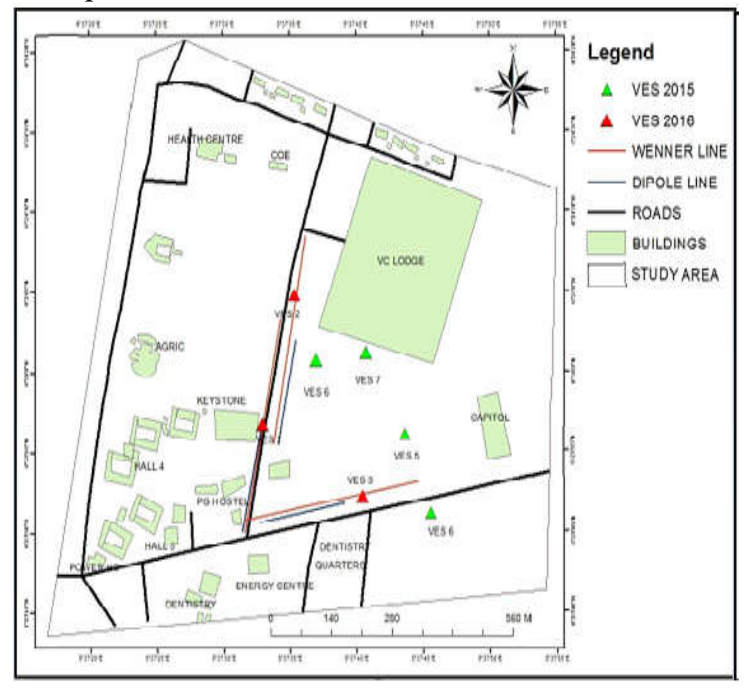

Fig. 1: Map of the study area

Although transportation and petty trading is the major business in the city, other activities engaged include two brewing factories, a petroleum storage depot and oil pipeline, furniture factories, four small-scale pharmaceutical production factories, metal works, and colour photo laboratories. Benin City falls within the tropical equatorial zone dominated by dry season (November - March) and wet seasons (April October). Short and Stauble (1967) had described the City as being underlain by sedimentary formation.

The formation is made up of top reddish clayey sand capping highly porous fresh water bearing loose pebby sands, and sandstone with local thin clays and shale interbeds which are considered to be of braided stream origin. Erah et al., (2002) had reported that the sands, sandstones and clays vary in colour from reddish brown to pinkish yellow on weathered surfaces to white in the deeper fresh surfaces, and that limonitic coatings are responsible for the brown reddishyellowish colour.

They also reported that the formation is covered with loose brownish sand (quaternary drift) varying in thickness and is about $800 \mathrm{~m}$ thick; almost all of which is water bearing with water level varying from about $20 \mathrm{~m}$ to $52 \mathrm{~m}$.

It is generally believed to be highly permeable, porous and prolific in water yield. Short and Stauble (1967) reported that the aquifer yields range from $28.4 \mathrm{~m} 3 \mathrm{hr}-$ 1 at Iyanomo (south of the City), $125 \mathrm{~m} 3 \mathrm{hr}-1$ at Uselu (central part) to $208 \mathrm{~m} 3 \mathrm{hr}-1$ at Ogba (northern part) with a draw down ranging from $4.8 \mathrm{~m}$ at Iyanomo, 1.8 $\mathrm{m}$ at Uselu to $6.7 \mathrm{~m}$ at Ogba.

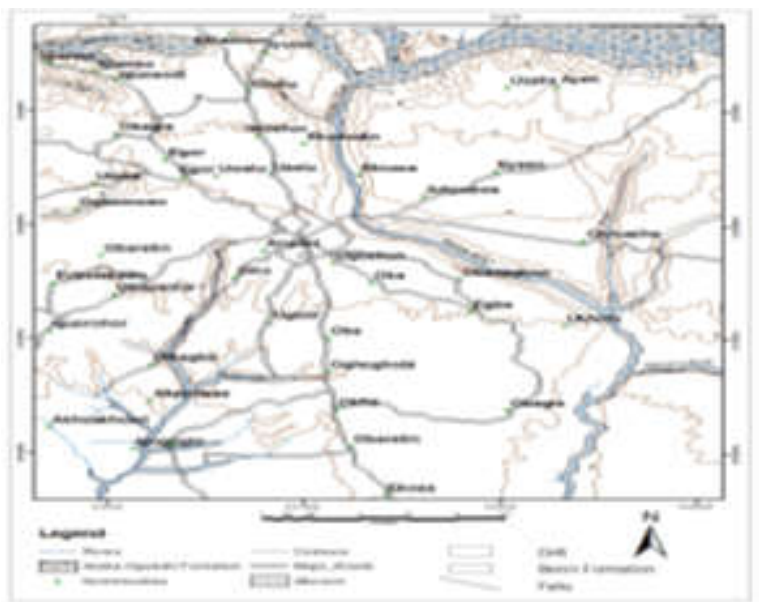

Fig. 2: Benin region geological formation (source: Akujieze, 2004)

Method: In this research work, the schlumberger array in electrical resistivity survey was adopted. The basic field equipment for this study is the ABEM terrameter which displays apparent resistivity values digitally as computed from ohms law. It is powered by a $12.5 \mathrm{v}$ D.C power source. Other accessories attached to the terrameter includes the booster, four metal electrodes, cables for current and potential electrodes, hammers, measuring tapes, walking talking or phones for very long spread.

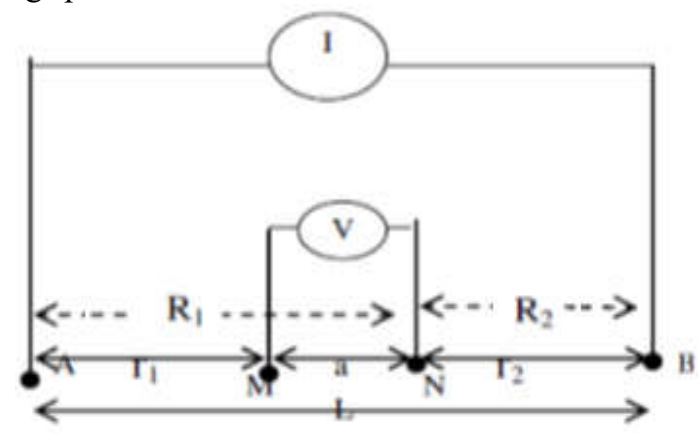

Fig 3: Schlumberger Field Electrode Configuration.

Where " $a$ " is the distance between the potential electrodes, $\mathrm{L}$ is the distance between current electrodes. Okwueze and Ezeanyim (1985), Zohdy (1988).

In this configuration, the four electrodes are positioned symmetrically along a straight line, the current electrodes on the outside and the potential electrodes on the inside. To change the depth range of the measurements, the current electrodes are displaced outwards while the potential electrodes in general are left at the same position. The resistance readings were used for computing the apparent resistivity using Schlumberger electrode configuration based on the following relationship: 
Where, $\rho$ is the apparent resistivity, $\mathrm{V}$ is the potential difference (volt, $\mathrm{V}$ ) and $I$ is the electric current (ampere, A).

$$
V=U_{M}-U_{N}=\frac{\rho l}{2 \pi}\left[\frac{1}{A M}-\frac{1}{B M}+\frac{1}{B N}-\frac{1}{A N}\right]
$$

Where, $U_{M}$ and $U_{N}=$ potentials at $M$ and $N$,; $A M=$ distance between electrodes $A$ and $M$, etc.

These distances are always the actual distances between the respective electrodes, whether or not they lie on a line. The quantity inside the brackets is a function only of the various electrode spacing. The quantity is denoted $1 / K$, which allows rewriting the equation as:

$$
V=\frac{\rho l}{2 \pi}\left[\frac{1}{K}\right]
$$

Where $K=$ array geometric factor that depends on the arrangement of the four electrodes A, B, M and N. To obtain the resistivity, $\rho$ :

$$
\rho=2 \pi K \frac{V}{l}
$$

The resistivity of the medium can be found from measured values of $V, I$, and $K$.

The above relationships holds provided that the current electrode spread $\mathrm{AB} / 2$ is equal to or greater than five times the potential electrode spread $\mathrm{MN} / 2$ with the depth of investigation as a function of electrode spacing. Based on the prevailing geologic condition during the survey, a maximum outer electrode spacing of $215 \mathrm{~m}$ was made at the sounding station. When the ratio of the distance between the current electrodes to that between the potential electrodes becomes too large, the potential electrodes must also be displaced outwards otherwise the potential difference becomes too small to be measured with sufficient accuracy (koefoed, 1979). Measurements of current and potential electrode positions are marked such that

\section{$A B / 2 \geq M N / 2$,}

Where; $\mathrm{AB} / 2=$ current electrode spacing; $\mathrm{MN} / 2=$ potential electrode spacing.

The Vertical Electrical Sounding data are plotted and inverted using IPI2win software which creates a 1-D model from the sounding data. The geological interpretation was done using the representative values of resistivity while Strater 3 software was used to draw the 1D subsurface model for visualization. Dar Zarrouk parameters, longitudinal conductance and Transverse resistance of each geo-electric layer were computed. The transmissivity of an aquifer is directly proportional to its transverse resistance (Ward, 1990). The longitudinal conductance is directly proportional to the conductivity of geologic material. The electrical reflection coefficient of each geo-electric boundary; longitudinal conductance and transverse resistance were computed using the formulas:

$$
\begin{gathered}
R R C=\left[\left(\rho_{n}-\rho_{n-1} / \rho_{n}+\rho_{n-1}\right)\right] \\
R C=\left[\left(\rho_{n} / \rho_{n-1}\right)\right] \\
T=\sum h_{i} \rho_{i}=h_{1} \rho_{1}+h_{2} \rho_{2}+\cdots h_{n} \rho_{n}\left(o h m-m^{2}\right) \\
S=\sum h_{i} / \rho_{i}=h_{1} / \rho_{1}+h_{2} / \rho_{2} \ldots h_{n} / \rho_{n}(m h o)
\end{gathered}
$$

Where: $\mathrm{RRC}=$ Resistivity reflection coefficient; $\mathrm{RC}=$ Resistivity contrast; $\mathrm{T}=$ Total transverse resistance $\mathrm{S}=$ Total longitudinal conductance; $\rho_{\mathrm{n}}=$ Resistivity of the nth layer; $\rho_{n-1}=$ Resistivity of the (n-1) th layer $\mathrm{h}_{\mathrm{n}}=$ Thickness of the nth layer

\section{RESULTAND DISCUSSION}

The Vertical Electrical Sounding data obtained for the geophysical survey carried out at part of the University of Benin are presented in Table 1. Interpretation for VES 1 Data: The results of the interpreted resistivity data for VES 1 present two layer curve (A). The computer interpretation of the observed curve resolved the penetrated rocks at the site into (4) geo-electric layers. The first layer resistivity value is $257 \Omega \mathrm{m}$ with a depth of $0.5 \mathrm{~m}$ is interpreted as laterite; the second layer resistivity value is $672 \Omega \mathrm{m}$ with a depth of $10.8 \mathrm{~m}$ is laterite. The third layer resistivity value is $18913 \Omega \mathrm{m}$ with depth $36.1 \mathrm{~m}$ is interpreted also as laterite, while the fourth layer resistivity value is $198.0 \Omega \mathrm{m}$ with a depth to infinity. Finally, the water table is suspected to lie in the fourth layer.

Interpretation for VES 2 Data: The results of the interpreted resistivity data for VES 2 presented an (HK) shape type curve. The computer interpretation of the observed curve resolved the penetrated rocks at the site into (5) geo-electric layers. The first layer resistivity value is $570 \Omega \mathrm{m}$ with a depth of $1.56 \mathrm{~m}$ is interpreted as Topsoil; the second layer resistivity value is $220 \Omega \mathrm{m}$ with a depth of $3.86 \mathrm{~m}$ is laterite.

The third layer resistivity value is $2098 \Omega \mathrm{m}$ with depth $29.8 .1 \mathrm{~m}$ is interpreted as laterite, the fourth layer resistivity value is $613.0 \Omega \mathrm{m}$ with a depth of $83.3 \mathrm{~m}$ is interpreted as Dry Sand. The fifth layer resistivity value is $22816 \Omega \mathrm{m}$ with depth to infinity. 
Geo-electrical Resistivity Evaluation of Groundwater.....

Table 1: Vertical Electrical Sounding 1 data

\begin{tabular}{|c|c|c|c|c|c|c|c|c|}
\hline \multirow{2}{*}{$\begin{array}{l}\text { Location } \\
\text { S/N }\end{array}$} & \multicolumn{2}{|c|}{ VC Lodge } & \multirow{2}{*}{$\begin{array}{l}\text { VES } 1 \\
\text { MN/2 (m) }\end{array}$} & \multirow{2}{*}{$\begin{array}{l}\text { Latitude } \\
\text { Longitude } \\
\text { R( }(\Omega)\end{array}$} & \multicolumn{2}{|c|}{$\mathrm{N}^{\mathrm{O}} 23^{\prime} 56.69^{\prime \prime}$} & \multirow[b]{2}{*}{ Observed } & \multirow[b]{2}{*}{$\begin{array}{l}\text { Computed } \\
\varrho_{\mathrm{a}}(\Omega \mathrm{m})\end{array}$} \\
\hline & \multicolumn{2}{|c|}{$\mathrm{AB} / 2(\mathrm{~m})$} & & & \multicolumn{2}{|c|}{$\begin{array}{l}\mathrm{E}^{0} 37^{\prime} 32.83^{\prime \prime} \\
\mathbf{K}\end{array}$} & & \\
\hline 1 & \multicolumn{2}{|c|}{1.0} & 0.2 & 45.8 & \multicolumn{2}{|c|}{7.54} & 345.33 & 345.3 \\
\hline 2 & \multicolumn{2}{|l|}{1.47} & 0.2 & 24.7 & \multicolumn{2}{|l|}{16.66} & 411.5 & 411.5 \\
\hline 3 & \multicolumn{2}{|l|}{2.15} & 0.2 & 13.67 & \multicolumn{2}{|l|}{35.99} & 491.98 & 492 \\
\hline 4 & \multicolumn{2}{|l|}{3.16} & 0.2 & 7.38 & \multicolumn{2}{|l|}{73.12} & 539.63 & 539.6 \\
\hline 5 & \multicolumn{2}{|l|}{4.64} & 0.2 & 3.62 & \multicolumn{2}{|l|}{168.80} & 611.06 & 611.1 \\
\hline 6 & \multicolumn{2}{|l|}{6.81} & 0.2 & 2.15 & \multicolumn{2}{|l|}{363.17} & 780.82 & 653.82 \\
\hline 7 & \multicolumn{2}{|l|}{10.0} & 2.0 & 8.04 & \multicolumn{2}{|l|}{75.41} & 606.3 & 721.73 \\
\hline 8 & \multicolumn{2}{|l|}{14.7} & 2.0 & 4.63 & \multicolumn{2}{|l|}{166.60} & 771.36 & 879.45 \\
\hline 9 & 21.5 & & 2.0 & 2.59 & 359.96 & & 932.3 & 1126 \\
\hline 10 & 31.6 & & 2.0 & 2.03 & 781.22 & & 1585.88 & 1586 \\
\hline 11 & 46.4 & & 2.0 & 1.36 & 1688.01 & & 2295.69 & 2249 \\
\hline 12 & 68.1 & & 2.0 & 0.965 & 3639.70 & & 3512.31 & 2936 \\
\hline 13 & 100 & & 20 & 5.71 & 754 & & 4305.34 & 3474 \\
\hline 14 & 147 & & 20 & 2.32 & 1665.97 & & 3865.05 & 3865 \\
\hline 15 & 215 & & 20 & 0.78 & 3599.55 & & 2807.65 & 3722 \\
\hline & & & e 2: showing & ub-surface ch & aracteristics & $18 \mathrm{~L}$ & points & \\
\hline & Layer & & $\begin{array}{l}\text { 1: } \\
\text { tivity }(\Omega \mathrm{m})\end{array}$ & $\begin{array}{l}\text { Depth to } \\
\text { Top(m) }\end{array}$ & $\begin{array}{l}\text { Thickness } \\
\text { (m) }\end{array}$ & $\begin{array}{l}\text { Infe } \\
\text { Lith }\end{array}$ & d $\quad$ Rem & \\
\hline & 1 & 25 & & 8.5 & 0.5 & $\begin{array}{l}\text { Late } \\
\text { (wer }\end{array}$ & c & \\
\hline & 2 & 67 & & 11.3 & 10.8 & $\begin{array}{l}\text { Late } \\
\text { (we }\end{array}$ & red) & \\
\hline & 3 & & & 47.4 & 36.1 & Late & & \\
\hline & 4 & 19 & & - & - & San & Pote & \\
\hline
\end{tabular}

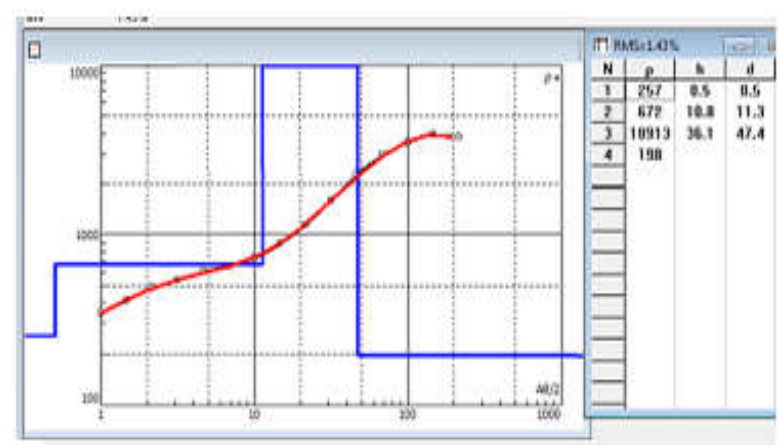

Fig. 4: Vertical Electrical Sounding data 1 Curve and model

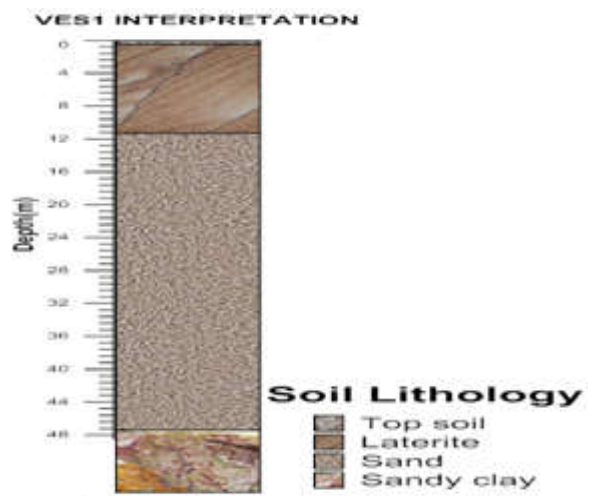

Fig. 5: Lithology of VES 1 interpretation

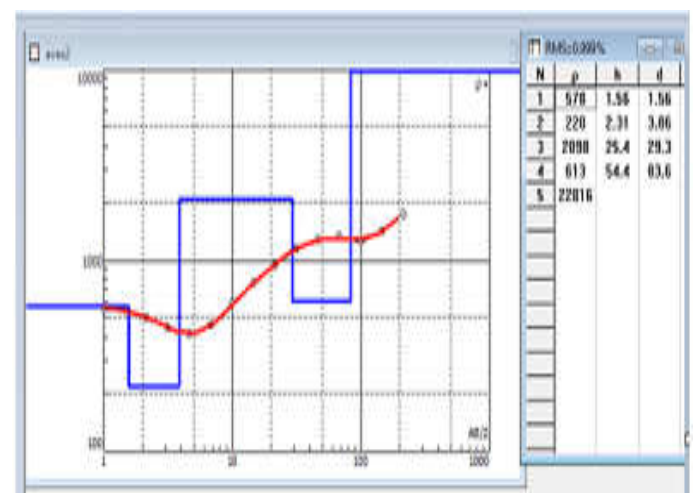

Fig. 6: VES 2 Model and Curve

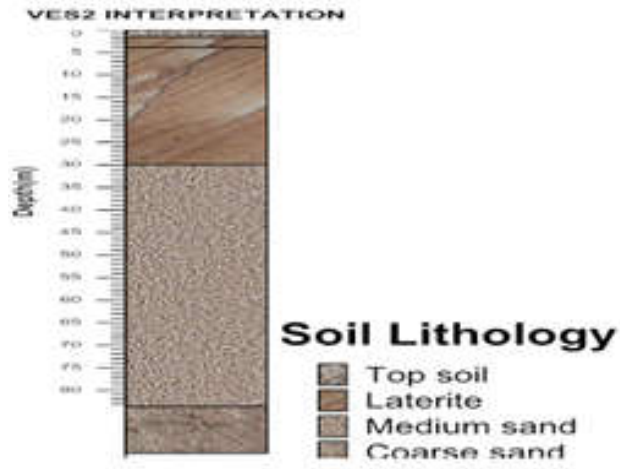

Fig. 7: Lithology of VES 2 interpretation 


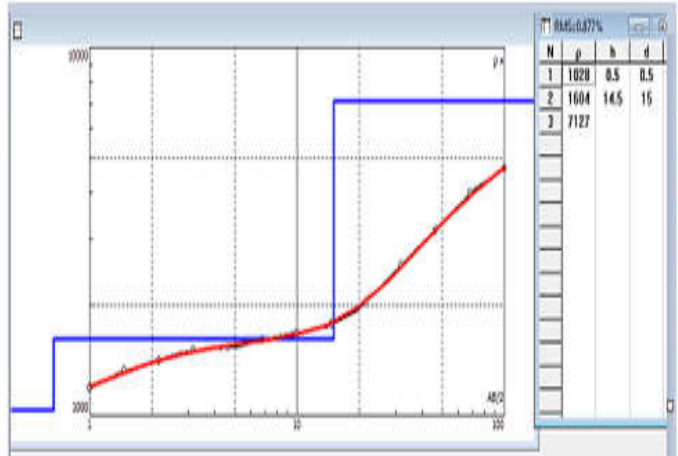

Fig. 8: Vertical Electrical Sounding 3 model and curve

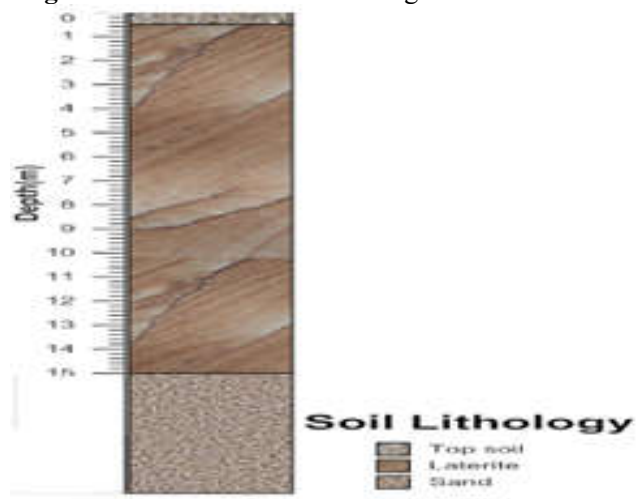

Fig. 9: Lithology of Vertical Electrical Sounding 3 interpretation
Interpretation for VES 2 Data: The results of the interpreted resistivity data for VES 2 presented an (HK) shape type curve. The computer interpretation of the observed curve resolved the penetrated rocks at the site into (5) geo-electric layers. The first layer resistivity value is $570 \Omega \mathrm{m}$ with a depth of $1.56 \mathrm{~m}$ is interpreted as Topsoil; the second layer resistivity value is $220 \Omega \mathrm{m}$ with a depth of $3.86 \mathrm{~m}$ is laterite. The third layer resistivity value is $2098 \Omega \mathrm{m}$ with depth $29.8 .1 \mathrm{~m}$ is interpreted as laterite, the fourth layer resistivity value is $613.0 \Omega \mathrm{m}$ with a depth of $83.3 \mathrm{~m}$ is interpreted as Dry Sand. The fifth layer resistivity value is $22816 \Omega \mathrm{m}$ with depth to infinity.

Interpretation For VES 3 Data: The results of the interpreted resistivity data for VES 3 presented an (A) shape type curve. The computer interpretation of the observed curve resolved the penetrated rocks at the site into (3) geo-electric layers. The first layer resistivity value is $1028 \Omega \mathrm{m}$ with a depth of $0.5 \mathrm{~m}$ is interpreted as Topsoil; the second layer resistivity value is $1604 \Omega \mathrm{m}$ with a depth of $15 \mathrm{~m}$ is laterite. The third layer resistivity value is $7127 \Omega \mathrm{m}$ with depth to infinity is interpreted as laterite, This VES point shows no striking potential for underground water potential

Table 3: Vertical Electrical Sounding 2 data

\begin{tabular}{|c|c|c|c|c|c|c|}
\hline $\begin{array}{l}\text { Location } \\
\mathrm{S} / \mathrm{N}\end{array}$ & $\begin{array}{l}\text { VC Lodge Area } \\
\mathbf{A B} / \mathbf{2}(\mathbf{m})\end{array}$ & $\begin{array}{l}\text { VES 2 } \\
\text { MN/2 (m) }\end{array}$ & $\begin{array}{l}\text { Latitude } \\
\text { Longitude } \\
\mathbf{R}(\Omega)\end{array}$ & $\begin{array}{l}\mathrm{N}^{\mathrm{O}} 24^{\prime} 4.87^{\prime \prime} \\
\mathrm{E}^{0} 37^{\prime} 35.21^{\prime \prime} \\
\mathbf{K}\end{array}$ & $\begin{array}{l}\text { Observed } \\
\mathrm{Q}_{a}(\Omega \mathrm{m})\end{array}$ & $\begin{array}{l}\text { Computed } \\
\mathrm{Q}_{\mathrm{a}}(\Omega \mathrm{m})\end{array}$ \\
\hline 1 & 1.0 & 0.2 & 64.8 & 7.54 & 488.59 & 467.23 \\
\hline 2 & 1.47 & 0.2 & 32.4 & 16.66 & 539.78 & 458 \\
\hline 3 & 2.15 & 0.2 & 12.82 & 35.99 & 461.39 & 419 \\
\hline 4 & 3.16 & 0.2 & 6.22 & 73.12 & 454.81 & 372 \\
\hline 5 & 4.64 & 0.2 & 2.12 & 168.80 & 357.86 & 343 \\
\hline 6 & 6.81 & 0.2 & 1.225 & 363.17 & 444.88 & 383 \\
\hline 7 & 10.0 & 2.0 & 8.75 & 75.41 & 659.84 & 495.7 \\
\hline 8 & 14.7 & 2.0 & 3.82 & 166.60 & 636.41 & 636 \\
\hline 9 & 21.5 & 2.0 & 2.15 & 359.96 & 773.91 & 788 \\
\hline 10 & 31.6 & 2.0 & 1.35 & 781.22 & 1054.65 & 961.2 \\
\hline 11 & 46.4 & 2.0 & 0.81 & 1688.01 & 1367.29 & 1061 \\
\hline 12 & 68.1 & 2.0 & 0.420 & 3639.70 & 1528.67 & 1115 \\
\hline 13 & 100 & 20 & 1.27 & 754 & 957.58 & 1051 \\
\hline 14 & 147 & 20 & 0.77 & 1665.97 & 1282.8 & 1195 \\
\hline 15 & 215 & 20 & 0.546 & 3599.55 & 1965.35 & 1456 \\
\hline 16 & 215 & 20 & 0.485 & 3599.55 & 1745.78 & 1746 \\
\hline
\end{tabular}

Table 4: showing sub-surface characteristics of VES 2 points

\begin{tabular}{|c|c|c|c|c|c|}
\hline Layer & $\begin{array}{l}\text { Resistivity } \\
(\Omega \mathrm{m})\end{array}$ & $\begin{array}{l}\text { Depth to } \\
\text { Top(m) }\end{array}$ & $\begin{array}{l}\text { Thickness } \\
\text { (m) }\end{array}$ & $\begin{array}{l}\text { Infer } \\
\text { Lithology }\end{array}$ & Remarks \\
\hline 1 & 578 & 1.56 & 1.56 & Top soil & \\
\hline 2 & 220 & 3.86 & 2.31 & Laterite & Weathered \\
\hline 3 & 2098 & 29.3 & 25.4 & Laterite & $\begin{array}{l}\text { Lower part of the laterite probably have } \\
\text { resistivity equivalent to the fine sand just overlain } \\
\text { it, for such a high geo-electric layer thickness. }\end{array}$ \\
\hline 4 & 613 & 83.6 & 54.4 & Sand & Dry Sand \\
\hline 5 & 22816 & - & - & Laterite & \\
\hline
\end{tabular}


Table 5: Vertical Electrical Sounding 3 data

\begin{tabular}{lllllll}
\hline Location & $\begin{array}{l}\text { VC Lodge } \\
\text { Area }\end{array}$ & VES 3 & $\begin{array}{l}\text { Latitude } \\
\text { Longitude }\end{array}$ & Observed & Computed \\
\hline $\mathbf{S} / \mathbf{N}$ & $\mathbf{A B} / \mathbf{2}(\mathbf{m})$ & $\mathbf{M N} / \mathbf{2}(\mathbf{m})$ & $\mathbf{R}(\mathbf{\Omega})$ & $\mathbf{K}$ & $\mathbf{0}_{\mathbf{a}}(\mathbf{\Omega m})$ & $\mathbf{Q}_{\mathbf{a}}(\mathbf{\Omega m})$ \\
\hline 1 & 1.0 & 0.2 & 157 & 7.54 & 1183.78 & 1184 \\
2 & 1.47 & 0.2 & 79.1 & 16.66 & 1317.81 & 1318 \\
3 & 2.15 & 0.2 & 39.1 & 35.99 & 1407.21 & 1407 \\
4 & 3.16 & 0.2 & 20.6 & 73.12 & 1506.27 & 1506 \\
5 & 4.64 & 0.2 & 9.46 & 168.80 & 1596.85 & 1525 \\
6 & 6.81 & 0.2 & 4.50 & 363.17 & 1634.27 & 1597 \\
7 & 10.0 & 0.2 & 2.13 & 785.19 & 1672.45 & 1672 \\
8 & 14.7 & 2.0 & 10.20 & 166.60 & 1699.32 & 1764 \\
9 & 21.5 & 2.0 & 4.37 & 359.96 & 1573.03 & 2026 \\
10 & 31.6 & 2.0 & 4.54 & 781.22 & 3546.74 & 2552 \\
11 & 46.4 & 2.0 & 1.59 & 1688.01 & 2683.94 & 3152 \\
12 & 68.1 & 2.0 & 1.18 & 3639.70 & 4294.85 & 3997 \\
13 & 100 & 2.0 & 0.58 & 7851 & 4553.58 & 4678 \\
\hline
\end{tabular}

Table 6: showing sub-surface characteristics of Vertical Electrical Sounding 3 point

\begin{tabular}{llllll}
\hline Layer & $\begin{array}{l}\text { VES3 } \\
\text { Resistivity } \\
(\mathbf{\Omega m})\end{array}$ & $\begin{array}{l}\text { Depth to } \\
\text { Top(m) }\end{array}$ & $\begin{array}{l}\text { Thickness } \\
(\mathbf{m})\end{array}$ & $\begin{array}{l}\text { Infer } \\
\text { Lithology }\end{array}$ & Remarks \\
\hline 1 & 1028 & 0.5 & 0.5 & Topsoil & Sandy \\
2 & 1604 & 15 & 14.5 & Laterite & \\
3 & 7127 & - & - & Laterite & \\
\hline
\end{tabular}

Table 7: Vertical Electrical Sounding 4 data

\begin{tabular}{|c|c|c|c|c|c|c|}
\hline \multirow[t]{2}{*}{ Location } & \multirow{2}{*}{$\begin{array}{l}\text { VC Lodge } \\
\text { (Capitol) }\end{array}$} & \multirow[t]{2}{*}{ VES 4} & \multirow{2}{*}{$\begin{array}{l}\text { Latitude } \\
\text { Longitude }\end{array}$} & \multicolumn{3}{|l|}{$\mathrm{N}^{\mathrm{O}} 23^{\prime} 51.2^{\prime \prime}$} \\
\hline & & & & E5 $5^{0} 37^{\prime} .45 .3^{\prime \prime}$ & Observed & Computed \\
\hline $\mathbf{S} / \mathbf{N}$ & $\mathrm{AB} / \mathbf{2}(\mathrm{m})$ & MN/2 (m) & $\mathbf{R}(\Omega)$ & K & $\mathrm{Q}_{\mathrm{a}}(\Omega \mathrm{m})$ & $\mathbf{Q}_{\mathrm{a}}(\Omega \mathrm{m})$ \\
\hline 1 & 1.0 & 0.2 & 146.5 & 7.54 & 1104.61 & 1195 \\
\hline 2 & 1.47 & 0.2 & 82.9 & 16.66 & 1381.11 & 1381 \\
\hline 3 & 2.15 & 0.2 & 44.7 & 35.99 & 1608.75 & 1609 \\
\hline 4 & 3.16 & 0.2 & 25.1 & 73.12 & 1835.31 & 1655 \\
\hline 5 & 4.64 & 0.2 & 12.52 & 168.80 & 2113.38 & 1827 \\
\hline 6 & 6.81 & 0.2 & 5.76 & 363.17 & 2091.86 & 1864 \\
\hline 7 & 10.0 & 0.2 & 2.02 & 785.19 & 1586.08 & 1864 \\
\hline 8 & 14.7 & 0.2 & 1.06 & 1697 & 1798.82 & 2017 \\
\hline 9 & 21.5 & 1.0 & 2.77 & 726 & 2011.02 & 2162 \\
\hline 10 & 31.6 & 1.0 & 1.60 & 1569 & 2510.4 & 2510 \\
\hline 11 & 46.4 & 1.0 & 1.04 & 3382 & 3517.28 & 3241 \\
\hline 12 & 68.1 & 2.0 & 1.26 & 3639 & 4585.14 & 4585 \\
\hline 13 & 100 & 2.0 & 0.30 & 7851 & 2355.3 & 6410 \\
\hline 14 & 147 & 2.0 & 2.65 & 16969 & 44967.85 & 9708 \\
\hline
\end{tabular}

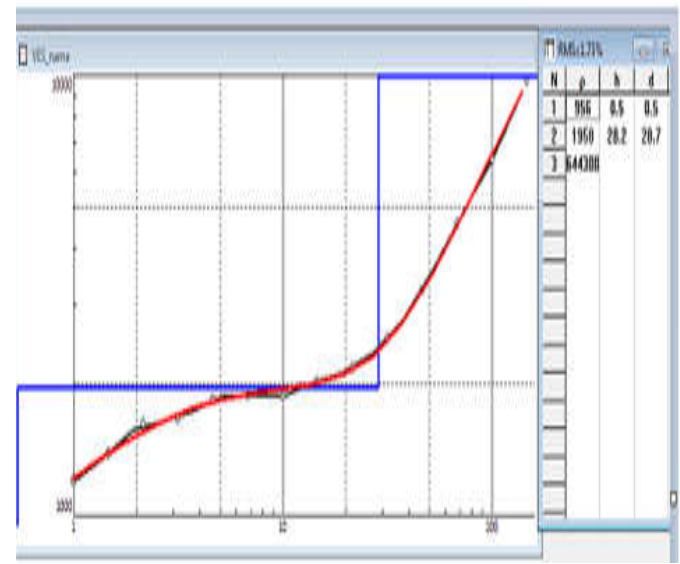

Fig. 10: Vertical Electrical Sounding 4 curve and mode

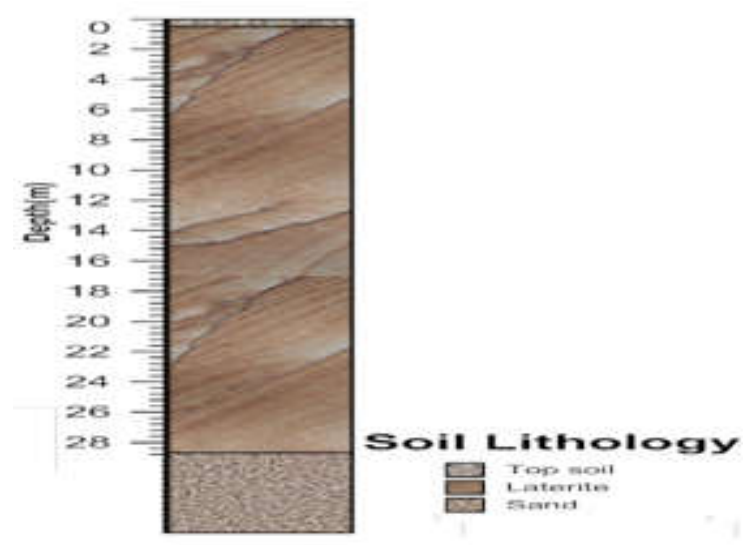

Fig 11: Lithology of Vertical Electrical Sounding 4 interpretation BASSEY, P; LAWRENCE, OO; AILEGO, J 


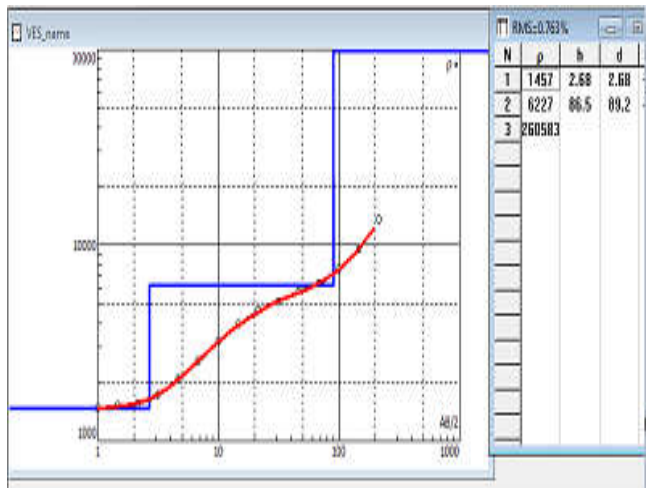

Fig. 12: VES 5 model and curve

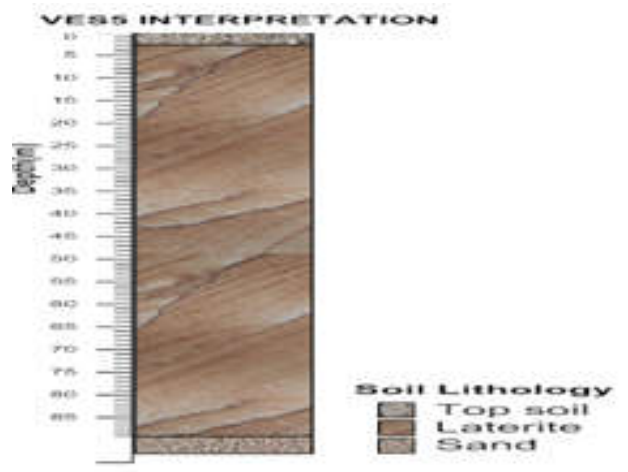

Fig. 13: Lithology of VES 5 interpretation

Interpretation for VES 4 Data: The results of the interpreted resistivity data for VES 4 presented an (A) shape type curve. The computer interpretation of the observed curve resolved the penetrated rocks at the site into (3) geo-electric layers. The first layer resistivity value is $956 \Omega \mathrm{m}$ with a depth of $0.5 \mathrm{~m}$ is interpreted as Topsoil; the second layer resistivity value is $1950 \Omega \mathrm{m}$ with a depth of $28.7 \mathrm{~m}$ is laterite. The third layer resistivity value is $644380 \Omega \mathrm{m}$ with depth to infinity is interpreted as laterite, This VES point shows no striking potential for underground water.

Interpretation for VES 5 Data: The results of the interpreted resistivity data for VES 5 presented a (K) shape type curve. The computer interpretation of the observed curve resolved the penetrated rocks at the site into (3) geo-electric layers. The first layer resistivity value is $1457 \Omega \mathrm{m}$ with a depth of $2.68 \mathrm{~m}$ is interpreted as Laterite; the second layer resistivity value is $6227 \Omega \mathrm{m}$ with a depth of $86.5 \mathrm{~m}$ is laterite. The third layer resistivity value is $260585 \Omega \mathrm{m}$ with depth to infinity is interpreted as laterite, This VES point shows no striking potential for underground water.

Table 8: showing sub-surface characteristics of Vertical Electrical Sounding 4 point

\begin{tabular}{|c|c|c|c|c|c|}
\hline Layer & $\begin{array}{l}\text { Resistivity } \\
(\Omega \mathrm{m})\end{array}$ & $\begin{array}{l}\text { Depth to } \\
\text { Top(m) }\end{array}$ & $\begin{array}{l}\text { Thickness } \\
\text { (m) }\end{array}$ & $\begin{array}{l}\text { Infer } \\
\text { Lithology }\end{array}$ & Remarks \\
\hline 1 & 956 & 0.5 & 0.5 & Top soil & Dry sand \\
\hline 2 & 1950 & 28.7 & 28.2 & Laterite & $\begin{array}{l}\text { The sediment just underlain it may have } \\
\text { equivalent resistivity with it, for such } \\
\text { high geo-electric layer thickness }\end{array}$ \\
\hline 3 & 644380 & - & - & Laterite & \\
\hline
\end{tabular}

\begin{tabular}{|c|c|c|c|c|c|c|}
\hline $\begin{array}{l}\text { Location } \\
\text { S/N }\end{array}$ & $\begin{array}{l}\text { VC Lodge } \\
\text { AB/2(m) }\end{array}$ & $\begin{array}{l}\text { VES5 } \\
\text { MN/2 (m) }\end{array}$ & $\begin{array}{l}\text { Latitude } \\
\text { Longitude } \\
\mathbf{R}(\Omega)\end{array}$ & $\begin{array}{l}\mathrm{N} 6^{\circ} 23^{\prime} 52.9^{\prime \prime} \\
\text { E5 }^{0} 37^{\prime} 44.5^{\prime \prime} \\
\mathbf{K}\end{array}$ & $\begin{array}{l}\text { Observed } \\
\varrho_{\mathrm{a}}(\Omega \mathrm{m})\end{array}$ & $\begin{array}{l}\text { Computed } \\
\mathrm{Q}_{\mathrm{a}}(\Omega \mathrm{m})\end{array}$ \\
\hline 1 & 1.0 & 0.2 & 159.7 & 7.54 & 1204.14 & 1470 \\
\hline 2 & 1.47 & 0.2 & 77.3 & 16.66 & 1287.82 & 1514 \\
\hline 3 & 2.15 & 0.2 & 55.5 & 35.99 & 1997.45 & 1545 \\
\hline 4 & 3.16 & 0.2 & 29.1 & 73.12 & 2127.79 & 1705 \\
\hline 5 & 4.64 & 0.2 & 12.93 & 168.80 & 2182.58 & 2057 \\
\hline 6 & 6.81 & 0.2 & 7.06 & 363.17 & 2563.98 & 2564 \\
\hline 7 & 10.0 & 0.2 & 2.94 & 785.19 & 2308.46 & 3210 \\
\hline 8 & 14.7 & 0.2 & 1.61 & 1697 & 2732.17 & 3911 \\
\hline 9 & 21.5 & 0.2 & 2.24 & 3631 & 8133.44 & 4626 \\
\hline 10 & 31.6 & 1.0 & 2.54 & 1569 & 3985.26 & 5107 \\
\hline 11 & 46.4 & 1.0 & 2.34 & 3382 & 7913.88 & 5750 \\
\hline 12 & 68.1 & 1.0 & 1.16 & 7285 & 8450.6 & 6285 \\
\hline 13 & 100 & 2.0 & 0.47 & 7851 & 3689.97 & 7508 \\
\hline 14 & 147 & 2.0 & 0.46 & 16969 & 7805.74 & 9424 \\
\hline 15 & 215 & 2.0 & 0.87 & 36303 & 31583.61 & 13319 \\
\hline
\end{tabular}


Geo-electrical Resistivity Evaluation of Groundwater.....

Table 10: showing sub-surface characteristics of VES 5 point

\begin{tabular}{|c|c|c|c|c|c|}
\hline Layer & $\begin{array}{l}\text { VES 5 } \\
\text { Resistivity } \\
(\Omega \mathrm{m})\end{array}$ & $\begin{array}{l}\text { Depth to } \\
\text { Top(m) }\end{array}$ & $\begin{array}{l}\text { Thickness } \\
\text { (m) }\end{array}$ & $\begin{array}{l}\text { Infer } \\
\text { Lithology }\end{array}$ & Remarks \\
\hline 1 & 1457 & 2.68 & 2.68 & Laterite & Dry sand \\
\hline 2 & 6227 & 89.2 & 86.5 & Laterite & $\begin{array}{l}\text { The sediment just } \\
\text { underlain it may } \\
\text { equivalent resistivity } \\
\text { with it, for such a high } \\
\text { geo-electric layer } \\
\text { thickness }\end{array}$ \\
\hline 3 & 260583 & - & - & Laterite & \\
\hline
\end{tabular}

Table 11: VES 6 data

\begin{tabular}{|c|c|c|c|c|c|c|}
\hline \multirow[t]{2}{*}{ Location } & \multirow[t]{2}{*}{ Beside Keptonic Hostel } & \multirow[t]{2}{*}{ VES 6} & \multirow{2}{*}{\begin{tabular}{|l} 
Latitude \\
Longitude
\end{tabular}} & \multicolumn{3}{|l|}{$\mathrm{N}^{\mathrm{O}} 24^{\prime} 00.8$} \\
\hline & & & & E5037'36.9'” & Observed & Computed \\
\hline $\mathbf{S} / \mathbf{N}$ & $\mathrm{AB} / \mathbf{2}(\mathrm{m})$ & MN/2 (m) & $\mathbf{R}(\Omega)$ & $\mathbf{K}$ & $\mathbf{o}_{\mathrm{a}}(\mathbf{\Omega m})$ & $\mathbf{O}_{\mathrm{a}}(\mathbf{\Omega m})$ \\
\hline 1 & 1.0 & 0.2 & 63.3 & 7.54 & 477.28 & 477.3 \\
\hline 2 & 1.47 & 0.2 & 32.5 & 16.66 & 541.45 & 509.42 \\
\hline 3 & 2.15 & 0.2 & 15.42 & 35.99 & 554.97 & 555 \\
\hline 4 & 3.16 & 0.2 & 8.01 & 73.12 & 585.69 & 613.6 \\
\hline 5 & 4.64 & 0.2 & 4.50 & 168.80 & 759.6 & 759.6 \\
\hline 6 & 6.81 & 0.2 & 2.56 & 363.17 & 929.72 & 869.76 \\
\hline 7 & 10.0 & 0.2 & 1.20 & 785.19 & 942.23 & 942.2 \\
\hline 8 & 14.7 & 1.0 & 3.95 & 338 & 1335.1 & 1335 \\
\hline 9 & 21.5 & 1.0 & 1.84 & 726 & 1335.84 & 1645 \\
\hline 10 & 31.6 & 1.0 & 0.83 & 1569 & 1302.27 & 2353 \\
\hline 11 & 46.4 & 1.0 & 0.78 & 3382 & 2637.96 & 3695 \\
\hline 12 & 68.1 & 2.0 & 0.63 & 3639 & 2292.57 & 5275 \\
\hline 13 & 100 & 2.0 & 0.60 & 7851 & 4710.6 & 7558 \\
\hline 14 & 147 & 2.0 & 7.28 & 16969 & 123534.3 & 11503 \\
\hline 15 & 215 & 2.0 & 0.40 & 36303 & 14521.2 & 16298 \\
\hline
\end{tabular}

Interpretation for VES 6 Data: The results of the interpreted resistivity data for VES 6 presented a (A) shape type curve. The computer interpretation of the observed curve resolved the penetrated rocks at the site into (3) geo-electric layers. The first layer resistivity value is $465 \Omega \mathrm{m}$ with a depth of $1.36 \mathrm{~m}$ is interpreted as Laterite; the second layer resistivity value is $995 \Omega \mathrm{m}$ with a depth of $11.3 \mathrm{~m}$ is Sand (Dry Sand). The third layer resistivity value is $410502 \Omega \mathrm{m}$ with depth to infinity is interpreted as laterite, This VES point shows no striking potential for underground water.

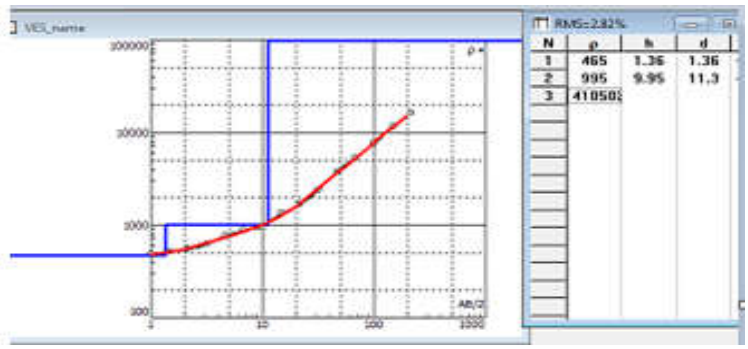

Fig. 14: VES 6 model and curve

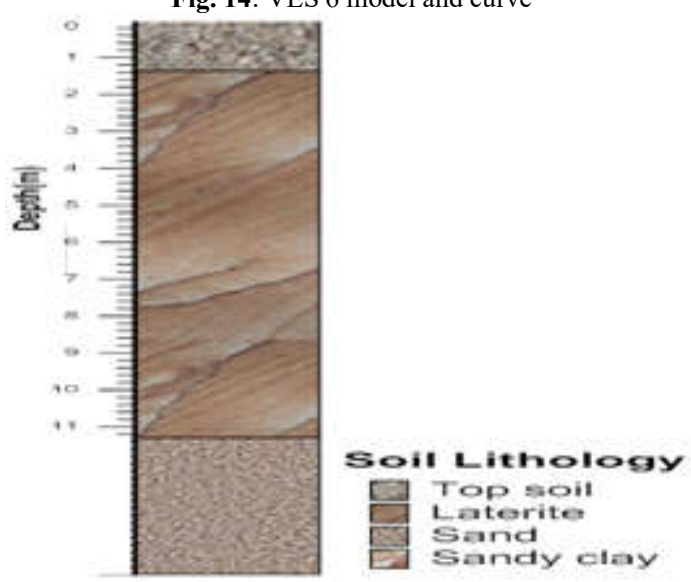

Fig. 15: Lithology of VES 6 interpretation

Table 12: showing sub-surface characteristics of VES 6 point

\begin{tabular}{llllll}
\multicolumn{6}{c}{ Table 12: showing sub-surface characteristics of VES 6 point } \\
\hline Layer & $\begin{array}{l}\text { VES 6 } \\
\text { Resistivity } \\
(\mathbf{\Omega m})\end{array}$ & $\begin{array}{l}\text { Depth to } \\
\text { Top(m) }\end{array}$ & $\begin{array}{l}\text { Thickness } \\
(\mathbf{m})\end{array}$ & $\begin{array}{l}\text { Infer } \\
\text { Lithology }\end{array}$ & Remarks \\
\hline 1 & 465 & 1.36 & 1.36 & Laterite & Weathered \\
2 & 995 & 11.3 & 9.95 & Sand & Dry \\
3 & 410502 & - & - & Laterite & Unsaturated \\
\hline
\end{tabular}


Table 13: Summary of table showing Dar Zarrouk Parameters of the Geo-electric Layers, RRC, RC, Thickness and Curve types

\begin{tabular}{|c|c|c|c|c|c|c|c|c|}
\hline $\begin{array}{l}\text { VES } \\
\text { Stations }\end{array}$ & $\begin{array}{l}\mathrm{T} \\
\left(\mathrm{Ohm}-\mathrm{m}^{2}\right)\end{array}$ & $\mathrm{S}$ (mho) & $\begin{array}{l}\text { Resistivity/Lithol } \\
\text { ogy of Potential } \\
\text { layers } \\
(\text { Ohm-m) }\end{array}$ & $\begin{array}{c}\mathrm{H}(\mathrm{m}) \\
\text { (thickness) }\end{array}$ & $\begin{array}{l}\mathrm{S} \text { (capacity } \\
\text { rating) }\end{array}$ & $\mathrm{RRC}$ & $\mathrm{RC}$ & $\begin{array}{l}\text { Curve } \\
\text { type }\end{array}$ \\
\hline 1 & 690310 & 0.002 & $\begin{array}{l}\text { 198/ layer 4- } \\
\text { Sandclay }\end{array}$ & Infinity & Poor & 0.90 & 0.01 & A \\
\hline 2 & 88046 & 0.11 & 613/ layer4-Sand & 54.4 & Poor & 0.80 & 9.5 & $\mathrm{HK}$ \\
\hline 3 & 23742 & 0.01 & No potential & - & Poor & 0.60 & 4.4 & A \\
\hline 4 & 63116 & 0.01 & No potential & - & Poor & 0.30 & 2.0 & $\mathrm{~A}$ \\
\hline 5 & 542540 & 0.01 & No potential & - & Poor & 0.62 & 4.27 & $\mathrm{~K}$ \\
\hline 6 & 731 & 0.01 & 995/layer2-Sand & 9.95 & Poor & -0.95 & 0.02 & $\mathrm{~A}$ \\
\hline
\end{tabular}

Table 14: Aquifer Capacity Rating

\begin{tabular}{ll}
\hline $\begin{array}{l}\text { Total Longitudinal } \\
\text { Conductance } \\
\text { Longitudinal }\end{array}$ & $\begin{array}{l}\text { Aquifer } \\
\text { Capacity } \\
\text { rating }\end{array}$ \\
$>10$ & \\
$5-10$ & Excellent \\
$0.7-4.9$ & Very good \\
$0.2-0.69$ & Good \\
$0.1-0.19$ & Moderate \\
$<0.1$ & Weak \\
\hline
\end{tabular}

Table 15: showing curve types of VES points

\begin{tabular}{lll}
\hline \multicolumn{3}{c}{ CURVE TYPES } \\
\hline VES 1 & A - type & $\sigma 1<\sigma 2<\sigma 3$ \\
VES 2 & HK -type & $\sigma 1<\sigma 2<\sigma 3>\sigma 4$ \\
VES 3 & A-type & $\sigma 1<\sigma 2<\sigma 3$ \\
VES 4 & A -type & $\sigma 1<\sigma 2<\sigma 3$ \\
VES 5 & K-type & $\sigma 1<\sigma 2>\sigma 3$ \\
VES 6 & A -type & $\sigma 1<\sigma 2<\sigma 3$ \\
\hline
\end{tabular}

Conclusion: Results obtained from this survey using Schlumberger Array, revealed the most dependable aquifer bearing zone and the lateral and vertical variation of subsurface lithology with distance and depth respectively. Results also revealed that the surveyed region has a subsurface generally characterized by laterite, which does not favor factors which will evolve a high yielding aquifer. Finally, Schlumberger array is recommended to probe for availability of groundwater compared to other methods because it gives a better vertical sounding and deeper depth probe.

Acknowledgment: The author wish to acknowledge Dr. S. A. Salami of Geology Department, University of Benin, for his immense contribution of assistance with some equipment and relevant guide that ensured a successful geophysical survey

\section{REFERENCES}

Akujieze, CN (2004). Effect of Anthropogenic Activities on Urban Groundwater System and Aquifer Vulnerability Assessment in Benin City, Edo State Nigeria. Ph.D. Thesis, University of Benin, Benin City, Nigeria.

Christensen, NB; Sorensen, KI (1998). Surface and Borehole Electric and Magnetic Methods for
Hydrogeological Investigations. European Journal of Environmental and Engineering Geophysics. 3: 75-90.

El-Arabi, HS (2008). Electrical Prospecting Methods. Department of Geology, Faculty of Science, Suez Canal University. University Publishing. Pp 64 66.

Erah, PO; Akujieze, CN; Oteze, GE (2002). The Quality of Groundwater in Benin City: A baseline study on inorganic chemicals and microbial contaminants of health importance in boreholes and open wells. Tropical Journal of Pharmaceutical Research; 1 (2): 75-82.

Ghosh, DP (1971). The Application of Linear Filter Theory to the Direct Interpretation of Geoelectrical Resistivity Sounding Measurements. Paper read at the 32nd Meeting of the European Association of Exploration Geophysicists at Edinburgh, May 1970.

Hadi, TN (2009). Geoelectric Investigation of the Aquifer Characteristics and Groundwater Potential in Behbahan Azad University Farm, Khuzestan Province, Iran. Journal of Applied Sciences. 9 (20): $3691-3698$

IPI2WIN software. Moscow State University, Version $3.0 ; 2003$.

Koefoed, O (1979). Geosounding Principles 1: Resistivity Sounding Measurements. Elsevier Science Publishing Company, Amsterdam.

Okwueze EE, Ezeanyim VI (1985). The Vertical Electrical Sounding (VES). method in Laterite regions and in iron rich glaciated areas. $J$. mining geol., 22(1-2): 193- 198.

Short, K; Stauble, AJ (1967). Outline of the geology of Niger Delta. Am Assoc Petroleum Geologists Bull 1967; 51: 761-79. 
Telford, WM; Geldart, LP; Sheriff, RE (1990). Applied Geophysics, second edition. Cambridge University Press.

Ward, SH (1990). Resistivity and Induced Polarization Methods in Geotechnical and Environmental Geophysics. Society of Exploration Geophysicists, Tulsa, 147-189.
Zohdy, AAR (1988). Groundwater exploration with Schlumberger sounding near Jean Nevada USGS open file Rep., 66: 188-291. 